\title{
Improved biodegradability of hardly- decomposable wastewaters from petrochemical industry through photo- Fenton method and determination of optimum operational conditions by response surface methodology
}

Mahmood Derakhshan and Mojtaba Fazeli*

\begin{abstract}
Background: Petrochemical wastewaters are highly polluting due to having various destructive materials such as aromatic hydrocarbons and heavy metal ions. Therefore, they need to be treated before disposal to the environment. However, due to low biodegradability, applying common treatment methods such as activated sludge is not feasible for these wastewaters.

Methods: Photo-Fenton is an advanced oxidation process which was applied to promote the biodegradability of hardly-decomposable petrochemical wastewaters. The wastewater samples were provided by Maroon and Karoon petrochemical plants, located in Mahshahr, Iran. To design the experiments and analyze the experimental results, response surface method with four variables (input COD and TDS concentrations and injected a dosage of $\mathrm{H} 2 \mathrm{O} 2$ and $\mathrm{Fe} 2+$ ) and four fixed parameters (temperature, $\mathrm{pH}$, retention time, and UV power) were used.

Results: The ranges of input COD, H2O2, Fe2+ and TDS were 1000 to $2500 \mathrm{mg} \mathrm{L}-1,1000$ to $4000 \mathrm{mg} L-1,500$ to $3000 \mathrm{mg} L-1$, and 4500 to $11,500 \mathrm{mg} L-1$, respectively. Average input BOD5/COD ratio was 0.09 . These ranges and values were determined according to the quality of the raw wastewater and experimental design. Output BOD5/COD ratio was varying between 0.3 and 0.6 , which declined with an increase of input COD. The results showed that the biodegradability of the industrial wastewater was promoted upon application of higher $\mathrm{H} 2 \mathrm{O} 2$ and $\mathrm{Fe} 2+$ concentrations. Meanwhile, TDS concentration had no significant effect on biodegradability of this wastewater. The following optimum conditions were resulted by evaluating the maximum efficiency of the reactor in enhancing the biodegradability of the wastewater: 1000 mg L- 1 input COD, 2668 mg L- 1 H2O2, 1655 mg L- 1 Fe2+, 8000 mg L- 1 TDS, 0.6 output BOD5/ COD, $852 \mathrm{mg} L-1$ output BOD5 and $939 \mathrm{mg} L-1$ output COD.
\end{abstract}

Conclusion: Photo-Fenton method is highly efficient for increasing the biodegradability of petrochemical wastewaters before applying biological wastewater treatment.

Keywords: Petrochemical wastewater, Photo-Fenton, Hardly-decomposable, Biodegradation

\footnotetext{
* Correspondence: m_fazeli@sbu.ac.ir

Faculty of Civil, Water and Environmental Engineering, Shahid Beheshti

University A.C, Abbaspour Boulevard, Hakimieh, Tehranpars, Tehran

17765-1719, Iran
}

(c) The Author(s). 2018 Open Access This article is distributed under the terms of the Creative Commons Attribution 4.0 International License (http://creativecommons.org/licenses/by/4.0/), which permits unrestricted use, distribution, and reproduction in any medium, provided you give appropriate credit to the original author(s) and the source, provide a link to the Creative Commons license, and indicate if changes were made. The Creative Commons Public Domain Dedication waiver (http://creativecommons.org/publicdomain/zero/1.0/) applies to the data made available in this article, unless otherwise stated. 


\section{Background}

Due to the existence of hazardous pollutants such as aromatic hydrocarbons in petrochemical wastewaters, direct discharge of them to the environment can contaminate the resources and threaten the health of species that live in their vicinity [1]. Hence, discharging petrochemical wastewaters with hazardous pollutants such as petrochemicals and hydrocarbons should follow specific rules and standards [2]. In this respect, petrochemical complexes are under pressure by environment protection campaigns and organizations to reduce their pollutants emission, reuse water, and decrease power consumption to decline carbon effects [3]. In this regard, many studies have attempted to develop new ecofriendly treatment methods with maximum efficiency of pollutant removal, separation, and disposal.

Using microalgal systems for nutrient removal [4, 5], aerobic granular sludge [6], using photocatalytic reactors [7] and applying anoxic/oxic process $[8,9]$ are the newest efforts which are carried out in order to treat petrochemical wastewaters efficiently. As it is obvious, due to the level of organic load and the variety of the contaminants in the wastewater streams in petrochemical industry, biological treatment techniques seem to be inevitable [10]. However, due to existence of different non-biodegradable compounds (mainly hydrocarbons) in petrochemical wastewaters, common biological treatment methods (e.g. activated sludge) are not practically feasible for being applied as the only method of treatment and an efficient pretreatment method is usually necessary to improve the biodegradability of wastewater [11]. Therefore, accelerating techniques which significantly improves wastewater biodegradability are usually employed to solve the problem of wastewater treatment in petrochemical complexes [12].

Advanced oxidation processes (AOPs) can be considered as an effective treatment method to deal with hardly-biodegradable pollutants in wastewaters from the petrochemical industry [13]. Such processes have recently received much attention because of their capabilities of pollutant removal and converting hardly-decomposable materials to biodegradable materials [14]. These methods are based on producing radicals that are highly reactive, non-selective and with high oxidation potency [15]. In general, these methods use free radicals as strong oxidants to break long chain and hardly-decomposable organic molecules to smaller ones, which often offer improved biodegradability and can be used to generate carbon dioxide upon complete degradation [16]. In AOPs, oxidizing agents such as ultrasound, $\mathrm{UV}, \mathrm{O}_{3}, \mathrm{TiO}_{2}$, and $\mathrm{H}_{2} \mathrm{O}_{2}$ are utilized solely or in combination with each other [17]. These methods are often combined with or complement to each other and are used prior to or after other major treatment processes [18]. It has to be noted that when using chemical oxidants, a complete oxidation of the pollutants is not concerned due to the related high costs. Hence, partial oxidation is an effective alternative to enhance biological treatment of specific compounds [19].

There are numerous oxidation methods for decomposition of hardly-biodegradable pollutants in complex wastewater such as petrochemical wastewaters [20]. Photo-Fenton is an effective method which is noticeably efficient for chemical oxidation of hardy-decomposable compounds in wastewater $[21,22]$. Classical Fenton reaction is a combination of hydrogen peroxide $\left(\mathrm{H}_{2} \mathrm{O}_{2}\right)$ and Ferro ions $\left(\mathrm{Fe}^{2+}\right)$ in an acidic medium that results in cleavage of $\mathrm{H}_{2} \mathrm{O}_{2}$ into hydroxyl ion and hydroxyl radical and oxidation of $\mathrm{Fe}^{2+}$ to $\mathrm{Fe}^{3+}[23,24]$. The reaction takes place at room temperature without input energy [25]. Also, this reaction requires a relatively short time compared to other AOPs [26]. Besides, the needed reactants are readily accessible, can be conveniently stored, and are safe for maintenance [27]. Fenton reaction processes are prompted upon light irradiation and changed to a process known as photo-Fenton [28, 29].

In the presence of UV light, a greater number of $\mathrm{OH}$ radicals are generated from both direct photolysis of $\mathrm{H}_{2} \mathrm{O}_{2}$ and UV radiative reaction with iron, in aqueous solutions [30] (Eq. 1-3). Therefore, in photo-Fenton process, more $\mathrm{OH}$ radicals can be produced and efficiency enhances consequently [31]. This method is based on $\mathrm{OH}$ radical generation, which acts as a very strong oxidant in the destruction of compounds that cannot be oxidized with common oxidants such as $\mathrm{O}_{2}$ and $\mathrm{O}_{3}$ [32]. These radicals react with the compounds in solution and initiate a set of oxidation reactions until the compounds reach to the desired decomposition degree or convert to inorganic compounds, completely [33]. The radical has a high oxidation tendency toward most materials, without resistance to any material or a specific group.

$$
\begin{aligned}
& \mathrm{H}_{2} \mathrm{O}_{2}+\mathrm{UV} \rightarrow 2 \mathrm{OH} \\
& \mathrm{Fe}^{3+}+\mathrm{H}_{2} \mathrm{O}+\mathrm{UV} \rightarrow \mathrm{Fe}^{2+}+\mathrm{H}^{+}+\mathrm{OH}^{0} \\
& \mathrm{Fe}(\mathrm{OH})_{2}^{+}+\mathrm{UV} \rightarrow \mathrm{Fe}^{2+}+\mathrm{OH}^{0}
\end{aligned}
$$

Furthermore, $\mathrm{OH}$ radicals have gained attraction because of their oxidation power, reasonable operational cost, water solubility, and avoiding production of toxic side products. Convenience, simplicity, and efficiency of Fenton process at constant removal rate have been proved elsewhere [34].

Different Fenton-based oxidation processes in petrochemical wastewater treatment have drawn more attention to themselves during last years. Davarnejad et al. (2014) had applied electro-Fenton method using aluminum and iron electrodes in order to treat petrochemical wastewater and had achieved 67 and 54\% of COD removal for iron and aluminum respectively [35]. In another study, Wang et al. (2015) had applied Fenton method in order to 
increase the biodegradability of petrochemical wastewater and had reduced the number of the polluting compounds in the wastewater from 117 to 27 most of which were biodegradable components [36]. Scaratti et al. (2017) applied heterogeneous photo-Fenton process for synthetic petrochemical wastewater using residue-based iron oxide nanocatalysts and graphene oxide in order to compare the influences of these two nanostructures on TOC and COD removal [37].

In this research, it is tried to increase the biodegradability of petrochemical wastewater using photo-Fenton process. The raw wastewaters from petrochemical plants of Maroon and Kroon in Mahshar petrochemical and economic zone, Iran, were used. Since $\mathrm{BOD}_{5} / \mathrm{COD}$ ratios of these wastewaters are low, they are categorized as hardly-biodegradable wastewaters and common biological treatment methods are not feasible for their treatment. The objective of this research is to enhance the biodegradability of petrochemical wastewaters through enhancing $\mathrm{BOD}_{5} / \mathrm{COD}$ ratio by photo-Fenton method. Applying photo-Fenton method in order to increase the biodegradability as a pre-treatment method for actual petrochemical wastewater is the main objective of this research.

\section{Methods}

\section{Experimental setup}

In this study, a rectangular cube glassy reactor with $80 \mathrm{~cm}$ length, $20 \mathrm{~cm}$ width and $20 \mathrm{~cm}$ height was used (Fig. 1).

A stirrer was placed on the top of the reactor for a complete mixing of the wastewater with chemicals. Moreover, UVC lamps with $60 \mathrm{~cm}$ length and $20 \mathrm{~W}$ powers (Philips, Netherlands) were installed in the center of the reactor. Inlets of hydrogen peroxide and $\mathrm{Fe}^{2+}$ are shown in Fig. 1. The experiments were considered to be in a batch state with $1 \mathrm{~h}$ retention time.

Fluid level height was $5 \mathrm{~cm}$ and the distance between the UV lamp and the fluid surface was $15 \mathrm{~cm}$. According to the height and length of the fluid $(5$ and $60 \mathrm{~cm}$, respectively), the volume of the reactor was considered to be $6000 \mathrm{~cm}^{3}$. Based on literature review and field studies, the retention time of $1 \mathrm{~h}$, the temperature of $25 \pm 2{ }^{\circ} \mathrm{C}$, and $\mathrm{pH}=3$ were concerned as fixed parameters.

\section{Chemicals and the specification tests}

The chemicals used in this study included hydrogen peroxide (Merck, 30\% w/w and $\mathrm{MW}=34 \mathrm{~g} \mathrm{~mol}^{-1}$ ), hydrated iron sulfate $\left(\mathrm{FeSO}_{4} \cdot 7 \mathrm{H}_{2} \mathrm{O}\right)$, methanol $\left(\mathrm{CH}_{3} \mathrm{OH}\right)$, sodium hydroxide $(\mathrm{NaOH})$, and sulfuric acid $\left(\mathrm{H}_{2} \mathrm{SO}_{4}\right)$. $\mathrm{COD}$ and $\mathrm{BOD}_{5}$ were measured at the reactor inlets and outlets. Also, TDS, $\mathrm{H}_{2} \mathrm{O}_{2}, \mathrm{Fe}^{2+}, \mathrm{pH}$, and temperature were measured based on standard methods [38].

\section{Wastewater composition}

Specification of the utilized raw wastewater are listed in Table 1. This wastewater was sampled from a mixture of output wastewaters from Maroon and Karoon petrochemical plants with 2 to 1 ratio. Sampling was performed in spring of 2016. To explore parameter properties in other seasons, when lower pollution level is usually expected, experimental trials of treatment system were used. The most remarkable feature of the used wastewater was a considerable amount of hardly-decomposable materials and a high TDS level.

As shown in Table 1, the sampled wastewaters were employed with the outlined ratios to achieve qualitative characteristics required for mixture experiments. According to Eq.4, different parameters with experimental responses were compared to acquire mixed raw wastewater.

$$
\begin{aligned}
& \left(P_{i m} \times 2\right)+\left(P_{i k} \times 1\right)+\left(P_{s k} \times 0.5\right) \\
& \quad=\left(P_{m} \times 3.5\right)
\end{aligned}
$$

where $\mathrm{P}_{\mathrm{im}}$ is the parameter regarding Maroon petrochemical industry wastewater, $\mathrm{P}_{\mathrm{ik}}$ is the intended parameter corresponding to Karoon petrochemical industry wastewater, $\mathrm{P}_{\mathrm{sk}}$ is the parameter related to Karoon sanitary petrochemical wastewater, and $\mathrm{P}_{\mathrm{m}}$ is the parameter of interest associated with the mixed wastewater.

Based on the documents provided by the laboratory of the purgation unit for the other seasons of the year and also Table 1, the employed ranges of COD and TDS were selected to be 1000 to $2500 \mathrm{mg} \mathrm{L}^{-1}$ and 4500 to $11,500 \mathrm{mg} \mathrm{L}^{-1}$, respectively.

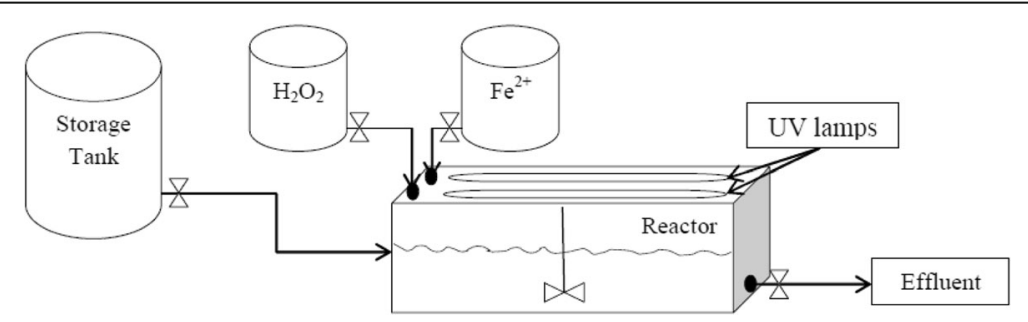

Fig. 1 Schematic illustration of the photo-Fenton reactor 
Table 1 Properties of the natural wastewater used in the experiments

\begin{tabular}{|c|c|c|c|c|}
\hline \multirow[t]{2}{*}{ Parameter } & \multicolumn{2}{|l|}{ Industrial wastewater } & \multirow{2}{*}{$\begin{array}{l}\text { Sanitary wastewater } \\
\text { Karoon petrochemical }\end{array}$} & \multirow{2}{*}{$\begin{array}{l}\text { Mix wastewater } \\
\text { for experimenta }\end{array}$} \\
\hline & Karoon petrochemical & Maroon petrochemical & & \\
\hline $\mathrm{COD}\left(\mathrm{mg} \mathrm{L}^{-1}\right)$ & 3980 & 742 & 81 & 2498 \\
\hline $\mathrm{BOD}_{5}\left(\mathrm{mg} \mathrm{L}^{-1}\right)$ & 345 & 70 & 64 & 226 \\
\hline $\operatorname{TDS}\left(\mathrm{mg} \mathrm{L}^{-1}\right)$ & 7050 & 24,350 & 1402 & 11,186 \\
\hline $\mathrm{pH}$ & 5 & 6.5 & 7 & 5.7 \\
\hline $\mathrm{BOD}_{5} / \mathrm{COD}$ & 0.09 & 0.09 & 0.8 & 0.09 \\
\hline Mix ratio & 2 & 1 & 0.5 & - \\
\hline
\end{tabular}

\section{Experiments conditions and procedure}

Experiments were conducted at common lab temperature of $25 \pm 2{ }^{\circ} \mathrm{C}$. The $\mathrm{pH}$ of all the samples which are entering the reactor were adjusted on 3 using $0.1 \mathrm{M} \mathrm{NaOH}$ and $0.1 \mathrm{M} \mathrm{H}_{2} \mathrm{SO}_{4}$ [39]. Then, a specific amount of hydrated iron sulfate was added to the reactor. The sample was then mixed with the chemicals and homogenized with the electrical stirrer. The materials were dissolved in the wastewater under UV radiation for $30 \mathrm{~min}$. Photo-Fenton experiment was initiated by gradual addition of hydrogen peroxide $\left(\mathrm{H}_{2} \mathrm{O}_{2}\right)$ [29]. To prevent excess reactions in the sample, $0.1 \mathrm{~mL}$ methanol was added to the reactor, at the end of the experiment [40]. Eventually, COD and $\mathrm{BOD}_{5}$ of the outlets were measured by $\mathrm{HACH} \mathrm{DR} / 2800$ and $\mathrm{HACH}$ BOD $(\mathrm{HACH}, \mathrm{US})$ instruments, respectively. The procedure was repeated for all trials.

\section{Experimental design and statistical analysis}

Response surface method (RSM) has been frequently used to perform statistical analysis and define optimum conditions. The advantages of this method are a reduced number of necessary experiments for result analysis and decreased experimental attempts [41]. In this study, central composite design (CCD) approach was adopted to carry out multi-variable modeling and analysis [42]. The experiment design in this study was through CCD method and by relying on four variable parameters of inlet COD concentration, $\mathrm{H}_{2} \mathrm{O}_{2}$ concentration, $\mathrm{Fe}^{2+}$ injected dosage and TDS concentration. Also, Design Expert 10.01 software was used to devise the experiments, carry out statistical analysis, model and determine optimum conditions. The variables were analyzed at 5 levels (Table 2). The

Table 2 The levels used in the parameters used in the test

\begin{tabular}{llllll}
\hline Parameters & -alpha & Low & Center & High & +alpha \\
\hline COD initial & 1000 & 1375 & 1750 & 2125 & 2500 \\
$\mathrm{H}_{2} \mathrm{O}_{2}$ & 1000 & 1750 & 2500 & 3250 & 4000 \\
$\mathrm{Fe}^{2+}$ & 500 & 1125 & 1750 & 2375 & 3000 \\
$\mathrm{TDS}$ & 4500 & 6250 & 8000 & 9750 & 11,500 \\
$(\mathrm{BOD} / \mathrm{COD})_{\mathbb{N N}}$ & 0.09 & & & & \\
$\mathrm{pH}$ & 3 & & & & \\
\hline
\end{tabular}

suggested number of experiments was randomly obtained to be 54 trials by considering 6 central repetitions and 2 repetitions in other points. Interactions between the variables and variance analysis of the data (ANOVA) were performed through RSM.

Quality of the model and the predicted values can be determined by an $\mathrm{R}^{2}$ coefficient. The variables used in this part are recorded by Eq. 5 .

$$
X_{i}=\frac{\left(x_{i}-x_{c p}\right)}{\Delta x_{i}}
$$

where $\mathrm{X}_{\mathrm{i}}$ is the encoded value of the $\mathrm{i}$-th independent parameter, $x_{i}$ the desired independent parameter, $x_{c p}$ is the value of the independent parameter in the central point, and $\Delta \mathrm{x}_{\mathrm{i}}$ is the value of the parameter change in each step. In the RSM method, the general form of the quadratic fitted equation is in accordance with Eq.6 [43].

$$
Y=\beta_{0}+\sum_{i=1}^{k} \beta_{i} X_{i}+\sum_{i=1}^{k} \beta_{i i} X_{i}^{2}+\sum_{i<j}^{k} \beta_{i j} X_{i} X_{j}+\varepsilon
$$

where $Y$ is the response variable and $\mathrm{BOD}_{5} / \mathrm{COD}$ ratio in the reactor outlet, $\beta_{O}$ is a constant, $\beta_{i}$ is linear coefficient, $\beta_{i i}$ refers to the second order effect of the model, $\beta_{i j}$ corresponds to the coefficient of mutual interaction and ${ }_{\varepsilon}$ is the statistical error.

\section{Results and discussion}

\section{Development and regression equations of the model}

The basis of the experimental procedure is the varying values of the independent variable, which was defined according to experimental results and literature review. Experimental design and the measured response are reported in Table 3. As the results illustrate, the empirical relationship between the independent variables and the response was obtained to be Eq.7 using Design expert software, in the framework of CCD method. 
Table 3 Experiment design according to RSM method and the measured response

\begin{tabular}{|c|c|c|c|c|c|c|c|c|c|c|c|}
\hline \multirow{2}{*}{$\begin{array}{l}\text { Test } \\
\text { number }\end{array}$} & \multicolumn{4}{|c|}{ Input variable parameters $\left(\mathrm{mg} \mathrm{L}^{-1}\right)$} & \multirow{2}{*}{$\begin{array}{l}\text { Response } \\
\text { BOD/COD }\end{array}$} & \multirow{2}{*}{$\begin{array}{l}\text { Test } \\
\text { number }\end{array}$} & \multicolumn{4}{|c|}{ Input variable parameters $\left(\mathrm{mg} \mathrm{L}^{-1}\right)$} & \multirow{2}{*}{$\begin{array}{l}\text { Response } \\
\text { BOD/COD }\end{array}$} \\
\hline & $\mathrm{COD}$ & $\mathrm{H}_{2} \mathrm{O}_{2}$ & $\mathrm{Fe}^{2+}$ & TDS & & & $\mathrm{COD}$ & $\mathrm{H}_{2} \mathrm{O}_{2}$ & $\mathrm{Fe}^{2+}$ & TDS & \\
\hline 1 & 1750 & 1000 & 1750 & 8000 & 0.299756 & 28 & 1750 & 4000 & 1750 & 8000 & 0.451106 \\
\hline 2 & 1375 & 1750 & 1125 & 9750 & 0.385659 & 29 & 2500 & 2500 & 1750 & 8000 & 0.356573 \\
\hline 3 & 2125 & 3250 & 1125 & 9750 & 0.374284 & 30 & 1750 & 2500 & 1750 & 8000 & 0.474479 \\
\hline 4 & 1750 & 2500 & 1750 & 11,500 & 0.421166 & 31 & 1750 & 2500 & 1750 & 8000 & 0.396539 \\
\hline 5 & 1375 & 1750 & 1125 & 9750 & 0.38932 & 32 & 1375 & 3250 & 1125 & 6250 & 0.503843 \\
\hline 6 & 1375 & 3250 & 2375 & 6250 & 0.581491 & 33 & 1375 & 3250 & 1125 & 6250 & 0.501281 \\
\hline 7 & 1750 & 4000 & 1750 & 8000 & 0.44911 & 34 & 1375 & 1750 & 1125 & 6250 & 0.388727 \\
\hline 8 & 1750 & 2500 & 1750 & 4500 & 0.424155 & 35 & 2125 & 3250 & 1125 & 6250 & 0.374841 \\
\hline 9 & 1750 & 2500 & 1750 & 8000 & 0.37437 & 36 & 2125 & 1750 & 2375 & 6250 & 0.336815 \\
\hline 10 & 1375 & 3250 & 2375 & 9750 & 0.581357 & 37 & 1375 & 1750 & 2375 & 9750 & 0.444746 \\
\hline 11 & 1000 & 2500 & 1750 & 8000 & 0.59867 & 38 & 2125 & 3250 & 2375 & 6250 & 0.428827 \\
\hline 12 & 2125 & 1750 & 1125 & 9750 & 0.300457 & 39 & 2125 & 3250 & 1125 & 6250 & 0.374444 \\
\hline 13 & 1750 & 2500 & 1750 & 8000 & 0.460101 & 40 & 1375 & 1750 & 2375 & 9750 & 0.444746 \\
\hline 14 & 1375 & 3250 & 2375 & 9750 & 0.581357 & 41 & 2125 & 3250 & 2375 & 9750 & 0.426278 \\
\hline 15 & 1375 & 1750 & 2375 & 6250 & 0.444545 & 42 & 1375 & 1750 & 2375 & 6250 & 0.443841 \\
\hline 16 & 2125 & 1750 & 1125 & 6250 & 0.301307 & 43 & 1750 & 2500 & 1750 & 11,500 & 0.422882 \\
\hline 17 & 1750 & 2500 & 500 & 8000 & 0.319115 & 44 & 2125 & 1750 & 2375 & 9750 & 0.337247 \\
\hline 18 & 1000 & 2500 & 1750 & 8000 & 0.599777 & 45 & 2500 & 2500 & 1750 & 8000 & 0.356953 \\
\hline 19 & 1750 & 2500 & 3000 & 8000 & 0.441197 & 46 & 1750 & 2500 & 3000 & 8000 & 0.442775 \\
\hline 20 & 1375 & 3250 & 2375 & 6250 & 0.581833 & 47 & 2125 & 1750 & 2375 & 9750 & 0.337247 \\
\hline 21 & 2125 & 3250 & 2375 & 6250 & 0.426786 & 48 & 2125 & 1750 & 1125 & 9750 & 0.30085 \\
\hline 22 & 2125 & 3250 & 2375 & 9750 & 0.426357 & 49 & 2125 & 1750 & 2375 & 6250 & 0.337467 \\
\hline 23 & 2125 & 1750 & 1125 & 6250 & 0.30085 & 50 & 1750 & 2500 & 500 & 8000 & 0.319653 \\
\hline 24 & 1375 & 3250 & 1125 & 9750 & 0.470356 & 51 & 2125 & 3250 & 1125 & 9750 & 0.375318 \\
\hline 25 & 1750 & 2500 & 1750 & 8000 & 0.422495 & 52 & 1375 & 1750 & 1125 & 6250 & 0.387379 \\
\hline 26 & 1750 & 2500 & 1750 & 8000 & 0.422799 & 53 & 1750 & 1000 & 1750 & 8000 & 0.300979 \\
\hline 27 & 1750 & 2500 & 1750 & 4500 & 0.422799 & 54 & 1375 & 3250 & 1125 & 9750 & 0.501288 \\
\hline
\end{tabular}

$$
\begin{aligned}
\frac{B O D_{5}}{C O D}= & 0.43-0.059 \times A+0.046 \times B+0.030 \\
& \times C+(5.829 E-003) \times B C+0.014 \\
& \times A^{2}-0.012 \times B^{2}-0.010 \times C^{2}
\end{aligned}
$$

Regression analysis was performed on the appropriate performance of the response. In the developed second order equation, $\mathrm{A}, \mathrm{B}$, and $\mathrm{C}$ stand for $\mathrm{COD}, \mathrm{H}_{2} \mathrm{O}_{2}$, and $\mathrm{Fe}^{2+}$, respectively. Eq.7 describes how $\mathrm{BOD}_{5} / \mathrm{COD}$ ratio is affected by each individual input variable or by mutual interaction of the variables. $\mathrm{BOD}_{5} / \mathrm{COD}$ ratio demonstrates linear and second order variations with respect to $\mathrm{COD}, \mathrm{H}_{2} \mathrm{O}_{2}$, and $\mathrm{Fe}^{2+}$, suggesting that the input independent parameters interact with each other [44].

As shown in Fig. 2, the photo-Fenton method has been very successful in the promoting the biodegradability of petrochemical wastewater. The rate of increase in all tested samples was more than $100 \%$, which in the most rate increased as $506 \%$. The $\mathrm{BOD}_{5} / \mathrm{COD}$ ratio also increased from 232 to $574 \%$.

\section{Analysis of variance of the data (ANOVA)}

ANOVA results (Table 4) show the success of the model and influence of the input factors on each other and the employed response.

The accuracy of the results and their consistency with the model was investigated through $\mathrm{F}$ values of the model and Lack of Fit. A model is accurate when its P and $F$ values are significant while its Lack of Fit is insignificant [45]. F value of the model is 151.26 which is significant. There is $0.01 \%$ probability of $\mathrm{F}$ value error. Prob > F values below 0.0500 show that the model parameters are statistically significant. In this study, the important $\mathrm{A}, \mathrm{B}, \mathrm{C}, \mathrm{A}^{2}, \mathrm{~B}^{2}$, and $\mathrm{C}^{2}$ parameters are 


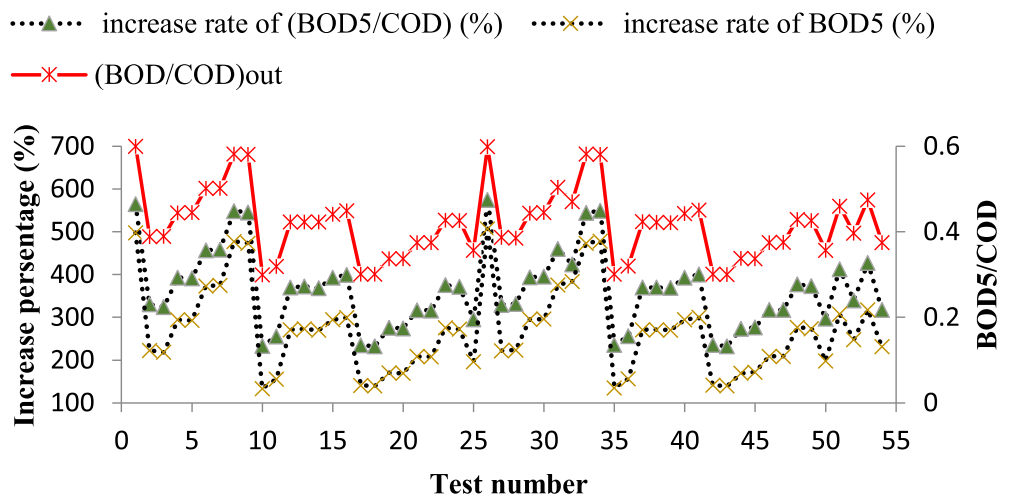

Fig. 2 The Photo-Fenton method results in increase BOD5 and (BOD5/COD) ratio

reported. F value for Lack of Fit is reported to be 1.65 that is negligible compared to the net error. There is an $11.49 \%$ possibility that a part of $F$ value in Lack of Fit result from the error. The insignificance of Lack of Fit is a good sign and declares the validity of the model. It means that the model relationships are statistically significant and can predict satisfactory responses.

Model consistency was evaluated by determining $R^{2}$ coefficient. In this study, $\mathrm{R}^{2}$ was obtained to be 0.9584 for $\mathrm{BOD}_{5} / \mathrm{COD}$ ratio. As $\mathrm{R}^{2}$ approximates unity, the model is stronger and the predicted responses are more reliable. The $R^{2}$ adj value was calculated to be 0.9520 that is a high value for biological decomposition and indicates significance and appropriateness of the model. $\mathrm{R}^{2}$ pred was 0.9454 that differs from the $R_{\text {adj }}^{2}$ value as much as 0.2 . This difference is logically acceptable. The low value of model's variance coefficient (C.V\%), i.e. 4.3, demonstrates precision and proper validity of the experiments $[46,47]$.

\section{Interactive impacts between the variables}

Influence of effective variable parameters on photo-Fenton process (i.e., COD, $\mathrm{H}_{2} \mathrm{O}_{2}, \mathrm{Fe}^{2+}$, and TDS) on degradation extent of hardly-decomposable organic compounds to molecules with high degradability is explained as follows. Fig. 3 presents interaction impacts of the selected parameters on degradability as a 3D graph.

Based on Fig. 3, input COD, $\mathrm{H}_{2} \mathrm{O}_{2}$, and $\mathrm{Fe}^{2+}$ parameters pose a noticeable impact on degradability but TDS does not show an effective role in biodegradation of wastewater contents. According to the results, the highest influence is due to input $\mathrm{COD}, \mathrm{Fe}^{2+}$, and $\mathrm{H}_{2} \mathrm{O}_{2}$, respectively.

\section{Evaluation of the effect of each independent variable on degradability}

The effect of each parameter on output $\mathrm{BOD}_{5} / \mathrm{COD}$ is depicted in Fig. 4. The experiments on each parameter

Table 4 Analysis of variance (ANOVA) for $\mathrm{BOD}_{5} / \mathrm{COD}$

\begin{tabular}{|c|c|c|c|c|c|c|}
\hline Source & SUM of Square & Degree of Freedom & Mean Square & F Value & P- Value Prob $>F$ & \\
\hline Model & 0.34 & 7 & 0.049 & 151.26 & $<0.0001$ & significant \\
\hline$A-C O D$ & 0.17 & 1 & 0.17 & 520.54 & $<0.0001$ & \\
\hline $\mathrm{B}-\mathrm{H}_{2} \mathrm{O}_{2}$ & 0.10 & 1 & 0.10 & 319.78 & $<0.0001$ & \\
\hline $\mathrm{C}-\mathrm{Fe}^{2+}$ & 0.042 & 1 & 0.042 & 130.14 & $<0.0001$ & \\
\hline$B C$ & $1.087 \mathrm{E}-003$ & 1 & 1.087E-003 & 3.36 & 0.0732 & \\
\hline$A^{2}$ & $9.264 \mathrm{E}-003$ & 1 & $9.264 \mathrm{E}-003$ & 28.65 & $<0.0001$ & \\
\hline$B^{2}$ & 6.679E-003 & 1 & $6.679 \mathrm{E}-003$ & 20.66 & $<0.0001$ & \\
\hline$C^{2}$ & $5.226 \mathrm{E}-003$ & 1 & $5.226 \mathrm{E}-003$ & 16.16 & 0.0002 & \\
\hline Residual & 0.015 & 46 & 3.233E-004 & & & \\
\hline Lack of Fit & 7.308E-003 & 17 & 4.299E-004 & 1.65 & 0.1149 & not significant \\
\hline Pure Error & 7.565E-003 & 29 & 2.608E-004 & & & \\
\hline Cor Total & 0.36 & 53 & & & & \\
\hline \multicolumn{7}{|l|}{$R^{2}=95.84 \%$} \\
\hline$R_{a d j}^{2}=95.20 \%$ & & & & & & \\
\hline
\end{tabular}




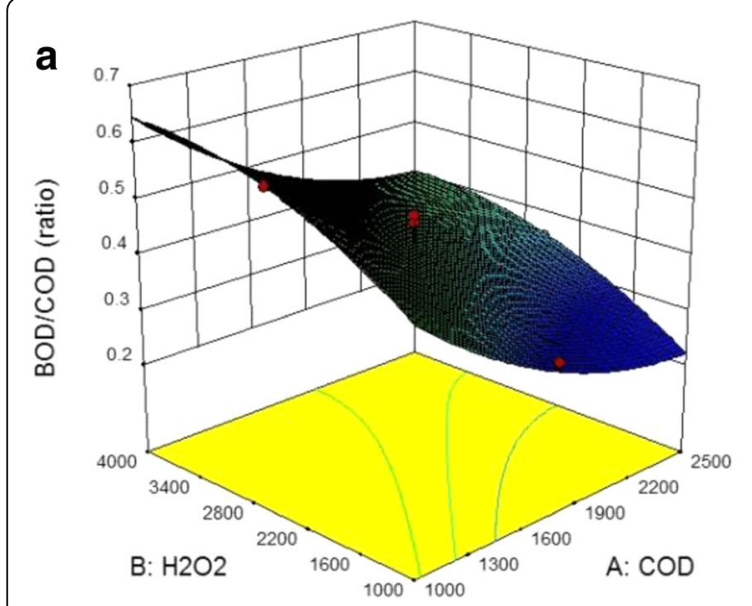

\section{Effect of input COD and $\mathrm{H}_{2} \mathrm{O}_{2}$ on degradability}

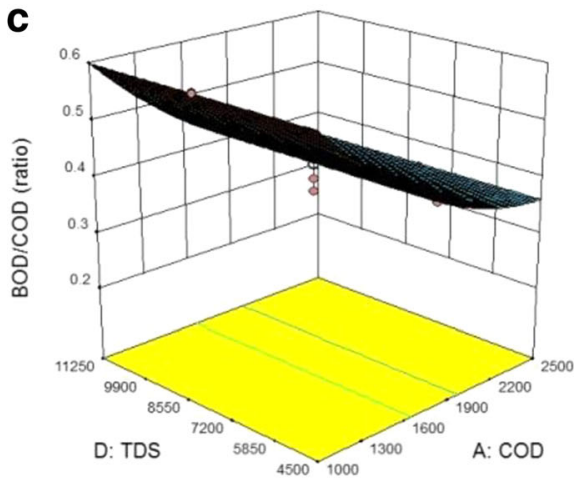

\section{Effect of input COD and TDS on degradability}

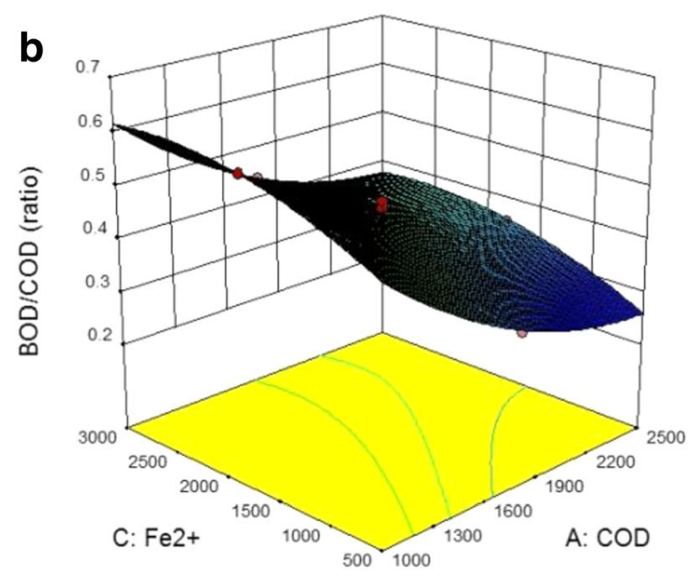

\section{Effect of input COD and $\mathrm{Fe}^{2+}$ on degradability}

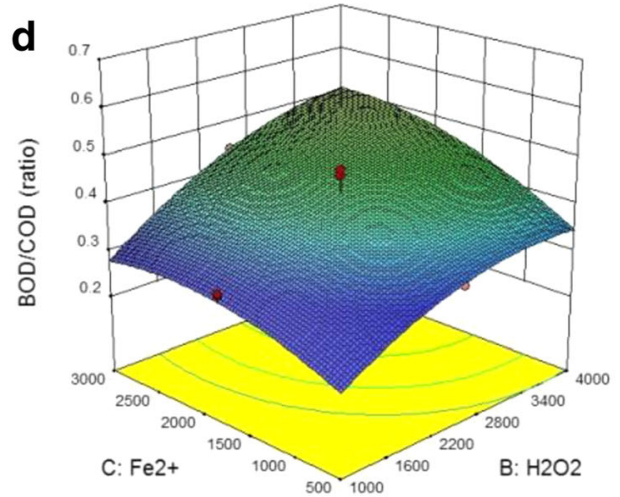

Effect of $\mathrm{Fe}^{2+}$ and $\mathrm{H}_{2} \mathrm{O}_{2}$ on degradability

Fig. 3 Effect of the variable parameters on degradability of wastewater in the outlet of photo-Fenton process. a Effect of input COD and $\mathrm{H}_{2} \mathrm{O}_{2}$ on degradability. $\mathbf{b}$ Effect of input COD and $\mathrm{Fe}^{2+}$ on degradability. c Effect of input COD and TDS on degradability. d Effect of Fe ${ }^{2+}$ and $\mathrm{H}_{2} \mathrm{O}_{2}$ on degradability

were performed at 5 different levels. As shown in Fig. 4a, wastewater degradability has decreased with input COD increase. This phenomenon is a consequence of the increased amount of materials that can be hardly decomposed in the wastewater inlet with an elevated amount of input COD. As less hardly-decomposable materials are in the wastewater, the $\mathrm{OH}$ radicals generated during photo-Fenton process decompose them more feasibly and widely. Accordingly, at the defined time, the organic molecules will be converted into biodegradable molecules more noticeably. The reported $\mathrm{BOD}_{5} / \mathrm{COD}$ ratio of this section varied from 0.36 to 0.60 .

As can be seen from Fig. $4 b$, output $\mathrm{BOD}_{5} / \mathrm{COD}$ ratio increases with $\mathrm{H}_{2} \mathrm{O}_{2}$ concentration up to $3250 \mathrm{mg} \mathrm{L}^{-1}$. This trend is an outcome of a promoted $\mathrm{OH}$ radical generation with accessibility to more $\mathrm{H}_{2} \mathrm{O}_{2}$ molecules. As can be seen from the figure, a degradability of 0.30 to 0.45 was achieved. According to Fig. 4c, higher concentrations of $\mathrm{Fe}^{2+}$ give an ascending trend of degradability due to a higher rate of $\mathrm{OH}$ radical production. The $\mathrm{BOD}_{5} / \mathrm{COD}$ ratio was reported to be within the range of 0.32 to 0.44 . No $\mathrm{BOD}_{5} / \mathrm{COD}$ increasing or decreasing effect was observed for TDS parameter on photo-Fenton process. In all conducted evaluations, the $\mathrm{BOD}_{5} / \mathrm{COD}$ ratio of the wastewater was reported to be 0.3 to 0.6 in photo-Fenton process. This finding demonstrates a high efficiency of photo-Fenton process in the provision of biodegradability for wastewaters with high contents of hardly-decomposable organic materials in saline mediums. 

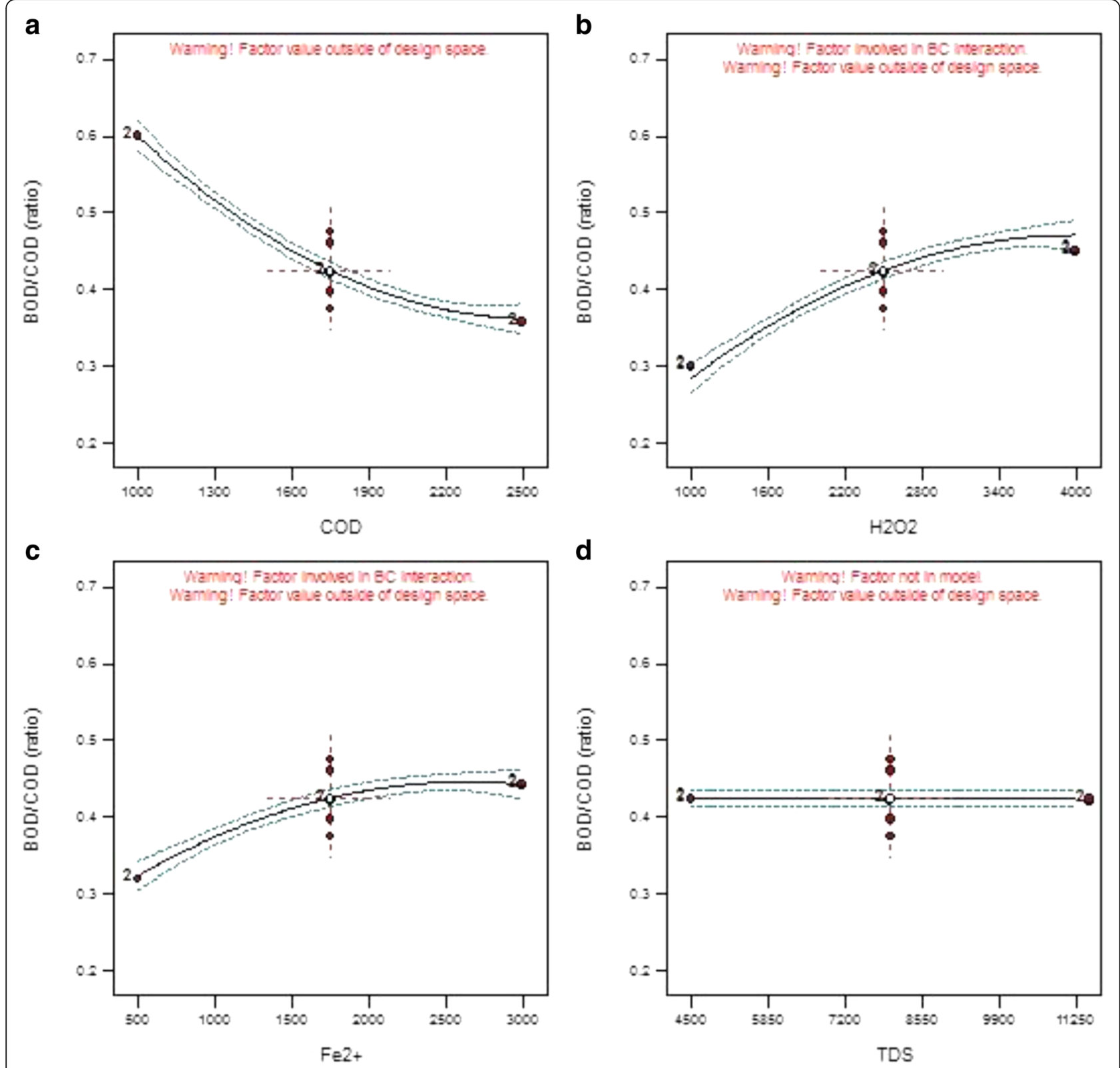

Fig. 4 Effect of each independent parameter on output BOD5/COD. a COD. b H2O2. c Fe2+. d TDS

\section{Optimum conditions}

According to the obtained results, selection of the optimum values of each parameter is crucial for the efficient performance of the reactor in purgation systems. Therefore, the outlined model was used to identify the optimum status in order to reach high degradability of the wastewater, from both operational and economic perspectives. According to Table 5, the values of $\mathrm{H}_{2} \mathrm{O}_{2}$, and $\mathrm{Fe}^{2+}$ consumption, which are economically important, were adjusted to their minimum values. Moreover, input COD and TDS, which varied with respect to the input wastewater, were kept in a certain range and the $\mathrm{BOD}_{5} / \mathrm{COD}$ ratio was
Table 5 Selection of different economic and operational statuses for an optimum point

\begin{tabular}{lll}
\hline Parameter & GOAL & Importance \\
\hline Inlet COD & in range & $* * *$ \\
$\mathrm{H}_{2} \mathrm{O}_{2}$ & minimize & $* * *$ \\
$\mathrm{Fe}^{2+}$ & minimize & $* * *$ \\
$\mathrm{TDS}$ & in range & $* * *$ \\
$\mathrm{BOD}_{5}(\mathrm{OUT})$ & in range & $* * *$ \\
$\mathrm{COD}(\mathrm{OUT})$ & in range & $* * *$ \\
$\mathrm{BOD}_{5} / \mathrm{COD}$ (ratio) & maximize & $* * * * *$ \\
\hline
\end{tabular}


Table 6 The most appropriate observed optimum condition for promotion of biodegradability

\begin{tabular}{|c|c|c|c|c|c|c|}
\hline Inlet COD $\left(\mathrm{mg} \mathrm{L}^{-1}\right)$ & $\mathrm{H}_{2} \mathrm{O}_{2}\left(\mathrm{mg} \mathrm{L}^{-1}\right)$ & $\mathrm{Fe}^{2+}\left(\mathrm{mg} \mathrm{L}^{-1}\right)$ & TDS $\left(\mathrm{mg} \mathrm{L}^{-1}\right)$ & Outlet COD $\left(\mathrm{mg} \mathrm{L}^{-1}\right)$ & Outlet $\mathrm{BOD}_{5}\left(\mathrm{mg} \mathrm{L}^{-1}\right)$ & $\mathrm{BOD}_{5} / \mathrm{COD}$ (ratio) \\
\hline 1000.04 & 2668.09 & 1655.44 & 5287.44 & 939 & 582 & 0.6 \\
\hline
\end{tabular}

considered to be the highest possible value in selecting the optimum points. A total of 24 optimum points were achieved by the model, among which the state provided in Table 6 was the best point.

As can be observed in Table 6, wastewater degradability is quite successful under optimum conditions. By maintaining the conditions of the wastewater entering treatment unit at the suggested values, the photo-Fenton process will provide a biological wastewater that can be treated by biological methods efficiently.

\section{Conclusion}

Using a successful modeling by Design Expert 10.0.1, it was found that three parameters of input $\mathrm{COD}, \mathrm{H}_{2} \mathrm{O}_{2}$, and $\mathrm{Fe}^{2+}$ have great impacts on conversion of hardly-decomposable materials into biodegradable molecules that can be purged by biological methods. TDS that is an indication of medium salinity did not pose any significant effect on photo-Fenton process. In all stages of the experiments by photo-Fenton method, $\mathrm{BOD}_{5} /$ COD ratio varied from 0.3 to 0.6. These values demonstrate the suitability of photo-Fenton process for decomposition of petrochemical industry wastewater into biodegradable materials in any experimental condition. The $\mathrm{BOD}_{5} / \mathrm{COD}$ ratio was reduced with input COD increase but enhanced by increasing injection dosages of $\mathrm{H}_{2} \mathrm{O}_{2}$ and $\mathrm{Fe}^{2+}$. The maximum $\mathrm{BOD}_{5} / \mathrm{COD}$ ratio was reported to be 0.6 that the high potential of photo-Fenton process in the decomposition of the wastewater materials into biodegradable compounds.

\section{Abbreviations \\ ANOVA: Analysis of variance; AOP: Advanced oxidation process; BOD: Biological oxygen demand; CCD: Central composite design; COD: Chemical oxygen demand; RSM: Response surface methodology; TDS: Total dissolved solids; UV: Ultra violet}

\section{Availability of data and materials}

All data generated or analysed during this study are included in this published article.

\section{Authors' contributions}

MD Carrying-out all of the experimental tests, producing the results and analyzing. Preparing the first manuscript. MF Supervising the experimental process and analyzing the resulta. Final editing of the manuscript. Both authors read and approved the final manuscript.

\section{Ethics approval and consent to participate}

Not applicable.

\section{Competing interests}

The authors declare that they have no competing interests.

\section{Publisher's Note}

Springer Nature remains neutral with regard to jurisdictional claims in published maps and institutional affiliations.

Received: 7 April 2018 Accepted: 4 June 2018

Published online: 20 June 2018

\section{References}

1. Li C, et al. Evaluation of petrochemical wastewater treatment technologies in Liaoning Province of China. Procedia Environ Sci. 2011;10:2798-802.

2. Crisafully $R$, et al. Removal of some polycyclic aromatic hydrocarbons from petrochemical wastewater using low-cost adsorbents of natural origin. Bioresour Technol. 2008;99(10):4515-9.

3. Capello C, et al. A comprehensive environmental assessment of petrochemical solvent production. Int J Life Cycle Assess. 2009;14(5):467-79.

4. Hodges A, et al. Nutrient and suspended solids removal from petrochemical wastewater via microalgal biofilm cultivation. Chemosphere. 2017;174:46-8.

5. Madadi $\mathrm{R}$, et al. Treatment of petrochemical wastewater by the green algae Chlorella vulgaris. International Journal of Environmental Research. 2016; 10(4):555-60.

6. Caluwé $\mathrm{M}$, et al. Formation of aerobic granular sludge during the treatment of petrochemical wastewater. Bioresour Technol. 2017;238:559-67.

7. Khaksar AM, et al. Treatment of phenol in petrochemical wastewater considering turbidity factor by backlight cascade photocatalytic reactor. J Photochem Photobiol A Chem. 2017;348:161-7.

8. Wu C, et al. Treatment of secondary effluent from a petrochemical wastewater treatment plant by ozonation-biological aerated filter. J Chem Technol Biotechnol. 2015;90(3):543-9.

9. Wu C, et al. Appling hydrolysis acidification-anoxic-oxic process in the treatment of petrochemical wastewater: from bench scale reactor to full scale wastewater treatment plant. J Hazard Mater. 2016;309:185-91.

10. Ding, P., L. Chu, and J. Wang, Advanced treatment of petrochemical wastewater by combined ozonation and biological aerated filter. Environ Sci Pollut Res, 2018: p. 1-10.

11. Vafajoo L, Ghanaat F, Ghalebi A. An investigation of a petrochemical wastewater treatment utilizing GAC: a study of adsorption kinetics. APCBEE procedia. 2014;10:131-5.

12. Shokrollahzadeh $\mathrm{S}$, et al. Biodegradation potential and bacterial diversity of a petrochemical wastewater treatment plant in Iran. Bioresour Technol. 2008;99(14):6127-33

13. Pignatello JJ, Oliveros E, MacKay A. Advanced oxidation processes for organic contaminant destruction based on the Fenton reaction and related chemistry. Crit Rev Environ Sci Technol. 2006;36(1):1-84.

14. Oturan MA, Aaron J-J. Advanced oxidation processes in water/wastewater treatment: principles and applications. A review. Crit Rev Environ Sci Technol. 2014:44(23):2577-641.

15. Mansour $D$, et al. Improvement of the activated sludge treatment by its combination with electro Fenton for the mineralization of sulfamethazine. International Biodeterioration \& Biodegradation. 2014;88:29-36.

16. Liu K, Roddick FA, Fan L. Impact of salinity and $\mathrm{pH}$ on the UVC/H2O2 treatment of reverse osmosis concentrate produced from municipal wastewater reclamation. Water Res. 2012:46(10):3229-39.

17. Dixit A, et al. Degradation of 2, 4 DCP by sequential biological-advanced oxidation process using UASB and UV/TiO2/H2O2. Desalination. 2011;272(13):265-9.

18. Wang $\lrcorner, \mathrm{Xu} L$. Advanced oxidation processes for wastewater treatment: formation of hydroxyl radical and application. Crit Rev Environ Sci Technol. 2012:42(3):251-325.

19. Poyatos JM, et al. Advanced oxidation processes for wastewater treatment: state of the art. Water Air Soil Pollut. 2010;205(1-4):187.

20. Andreozzi $R$, et al. Advanced oxidation processes (AOP) for water purification and recovery. Catal Today. 1999;53(1):51-9.

21. Bauer $\mathrm{R}$, Fallmann $\mathrm{H}$. The photo-Fenton oxidation-a cheap and efficient wastewater treatment method. Res Chem Intermed. 1997;23(4):341-54. 
22. Rubio-Clemente A, Chica E, Peñuela GA. Petrochemical wastewater treatment by photo-Fenton process. Water, Air, \& Soil Pollution. 2015;226(3):62

23. Mota, A., et al., Advanced oxidation processes and their application in the petroleum industry: a review. Brazilian J Pet and Gas, 2009. 2(3).

24. Li J, et al. Organics, sulfates and ammonia removal from acrylic fiber manufacturing wastewater using a combined Fenton-UASB (2 phase)-SBR system. Bioresour Technol. 2011;102(22):10319-26.

25. Bianco B, De Michelis I, Vegliò F. Fenton treatment of complex industrial wastewater: optimization of process conditions by surface response method. J Hazard Mater. 2011;186(2-3):1733-8.

26. Guedes AM, et al. Fenton oxidation of cork cooking wastewater-overall kinetic analysis. Water Res. 2003;37(13):3061-9.

27. Primo $\mathrm{O}$, et al. An integrated process, Fenton reaction- ultrafiltration, for the treatment of landfill leachate: pilot plant operation and analysis. Ind Eng Chem Res. 2008;47(3):946-52.

28. Funai DH, et al. Photo-Fenton treatment of valproate under UVC, UVA and simulated solar radiation. J Hazard Mater. 2017;323:537-49.

29. Arslan-Alaton I, Tureli G, Olmez-Hanci T. Treatment of azo dye production wastewaters using photo-Fenton-like advanced oxidation processes: optimization by response surface methodology. J Photochem Photobiol A Chem. 2009;202(2-3):142-53.

30. Ruppert G, Bauer R, Heisler G. The photo-Fenton reaction —an effective photochemical wastewater treatment process. J Photochem Photobiol A Chem. 1993;73(1):75-8.

31. Pignatello JJ. Dark and photoassisted iron (3+)-catalyzed degradation of chlorophenoxy herbicides by hydrogen peroxide. Environmental Science \& Technology. 1992;26(5):944-51.

32. Spacek W, Bauer R, Heisler G. Heterogeneous and homogeneous wastewater treatment-comparison between photodegradation with $\mathrm{TiO}_{2}$ and the photo-Fenton reaction. Chemosphere. 1995;30(3):477-84.

33. Perez $\mathrm{M}$, et al. Fenton and photo-Fenton oxidation of textile effluents. Water Res. 2002;36(11):2703-10.

34. Covinich $L G$, et al. Advanced oxidation processes for wastewater treatment in the pulp and paper industry: a review. American Journal of Environmental Engineering. 2014;4(3):56-70.

35. Davarnejad R, Mohammadi M, Ismail AF. Petrochemical wastewater treatment by electro-Fenton process using aluminum and iron electrodes: statistical comparison. Journal of Water Process Engineering. 2014:3:18-25.

36. Wang $Y$, et al. Treatment of petrochemical treatment plant secondary effluent by Fenton oxidation. Huan jing ke xue= Huanjing kexue. 2015;36(7): 2597-603.

37. Scaratti $G$, et al. Residue-based iron oxide catalyst for the degradation of simulated petrochemical wastewater via heterogeneous photo-Fenton process. Environ Technol. 2017:1-9.

38. Federation, W.E. and A.P.H. Association, Standard methods for the examination of water and wastewater. American Public Health Association (APHA): Washington, DC, USA, 2005

39. Benitez $F$, et al. The role of hydroxyl radicals for the decomposition of $\mathrm{p}$ hydroxy phenylacetic acid in aqueous solutions. Water Res. 2001;35(5):1338-43.

40. Sun, S.P., X. Zeng, and A.T. Lemley, Kinetics and mechanism of carbamazepine degradation by a modified Fenton-like reaction with ferricnitrilotriacetate complexes. J Hazard Mater, 2013. 252: p. 155-165.

41. Ferreira SC, et al. Box-Behnken design: an alternative for the optimization of analytical methods. Anal Chim Acta. 2007;597(2):179-86.

42. Birjandi N, Younesi $\mathrm{H}$, Bahramifar N. Treatment of wastewater effluents from paper-recycling plants by coagulation process and optimization of treatment conditions with response surface methodology. Appl Water Sci. 2016;6(4):339-48.

43. Khuri Al, Mukhopadhyay S. Response surface methodology. Wiley Interdisciplinary Reviews: Computational Statistics. 2010;2(2):128-49.

44. Mansouri $Y$, et al. Hydraulic characteristics analysis of an anaerobic rotatory biological contactor (AnRBC) using tracer experiments and response surface methodology (RSM). Korean J Chem Eng. 2012;29(7):891-902.

45. Ziagova M, et al. Comparative study of $\mathrm{cd}(\mathrm{II})$ and $\mathrm{Cr}(\mathrm{VI})$ biosorption on Staphylococcus xylosus and Pseudomonas sp. in single and binary mixtures. Bioresour Technol. 2007:98(15):2859-65.

46. Nakano E, Jutan A. Application of response surface methodology in controller fine-tuning. ISA Trans. 1994;33(4):353-66.

47. Collins LM, Dziak JJ, Li R. Design of experiments with multiple independent variables: a resource management perspective on complete and reduced factorial designs. Psychol Methods. 2009;14(3):202.

\section{Ready to submit your research? Choose BMC and benefit from:}

- fast, convenient online submission

- thorough peer review by experienced researchers in your field

- rapid publication on acceptance

- support for research data, including large and complex data types

- gold Open Access which fosters wider collaboration and increased citations

- maximum visibility for your research: over $100 \mathrm{M}$ website views per year

At BMC, research is always in progress.

Learn more biomedcentral.com/submissions 